\title{
Analisis Warna Berbasis Smartphone Android dan Aplikasinya dalam Pendugaan Umur Simpan Konsentrat Apel
}

\author{
Android Smartphone-based Color Analysis to Predict Shelf-life of Apple Juice Concentrate \\ Heru Kristanoko ${ }^{1}$, Feri Kusnandar ${ }^{2 *}$, Dian Herawati ${ }^{2}$ \\ ${ }^{1}$ Departemen Ilmu dan Teknologi Pangan, Fakultas Teknologi Pertanian, Institut Pertanian Bogor, \\ Kampus IPB Dramaga, Bogor, 16680, Indonesia \\ ${ }^{2}$ Southeast Asian Food and Agricultural Science and Technology Center, Institut Pertanian Bogor, \\ Kampus IPB Dramaga, Bogor, 16680, Indonesia \\ *Penulis korespondensi: Feri Kusnandar, Email: fkusnandar@apps.ipb.ac.id, heru_kristanoko@apps.ipb.ac.id
}

Tanggal submisi: 2 Mei 2020; Tanggal revisi: 9 April 2020; Tanggal penerimaan: 17 Juli 2020

\begin{abstract}
ABSTRAK
Warna merupakan salah satu parameter mutu penting dari konsentrat apel. Teknologi kamera smartphone yang semakin akurat dan mudah dioperasikan berpotensi untuk mengukur warna konsentrat apel. Penelitian ini bertujuan untuk mengevaluasi penggunaan kamera smartphone Android dalam mengukur perubahan warna model konsentrat apel dan pendugaan umur simpan konsentrat apel. Sampel konsentrat apel disimpan pada suhu 8, 15, dan $35^{\circ} \mathrm{C}$ masing-masing selama 25,20 , dan 14 hari. Nilai warna $L^{*}, a^{*}$, dan $b^{*}$ dari kolorimetri dibandingkan dengan nilai warna $R^{\prime}, G^{\prime}$, dan $B^{\prime}$ kamera. Nilai warna relatif $(r, g$, dan $b)$ digunakan untuk memperoleh hasil pengukuran warna dari kamera yang lebih akurat. Nilai $R^{\prime}$ pada kamera memiliki korelasi tertinggi dengan nilai $L^{*}$ kolorimetri pada pengukuran model konsentrat $(r=0,986)$. Nilai $r$ sebagai turunan nilai $R^{\prime}$ dapat menurunkan simpangan baku dari 4,66\% menjadi 1,36\%. Model Arrhenius dari nilai $r$ memberikan prediksi umur simpan 16,7 minggu yang mendekati prediksi dari nilai $L^{*}\left(17,2\right.$ minggu) pada suhu $25^{\circ} \mathrm{C}$.
\end{abstract}

Kata kunci: Reaksi pencoklatan; analisis warna; smartphone

\begin{abstract}
Color is one of the important quality parameters of apple concentrate. Meanwhile, smartphone camera technology with great accuracy and simple operation method is potential to measure the color of apple concentrate. This study aimed to evaluate the use of an Android smartphone camera in measuring the color change of apple concentrate model and to predict its shelf-life. The apple juice concentrate samples were stored at 8,15 , and $35^{\circ} \mathrm{C}$ for 25,20 , and 14 days, respectively, while the color values $\left(L^{*}, a^{*}\right.$, and $\left.b^{*}\right)$ from colorimetry were compared to the $R^{\prime}, G^{\prime}$, and $B^{\prime}$ of the camera. The relative color values $(r, g$, and $b)$ were used to obtain more accurate measurements from the camera. The value of $R^{\prime}$ on the camera had the highest correlation with $L^{*}$ colorimetry $(r=0,986)$, while $r$ as a derivative of $R^{\prime}$ reduced the standard deviation from $4.66 \%$ to $1.36 \%$. The Arrhenius model of $r$ predicted the product shelf life of 16,7 weeks which was relatively close to that of $L^{*}(17.2$ weeks $)$ at $25^{\circ} \mathrm{C}$.
\end{abstract}

Keywords: Browning reaction; color analysis; smartgphone 


\section{PENDAHULUAN}

Konsentrat apel merupakan hasil olahan buah apel yang banyak digunakan di industri pangan. Impor konsentrat apel ke Indonesia mencapai sekitar 88 ton per bulan, terutama dari Austria dan China (BPS, 2018). Konsentrat apel banyak digunakan karena harganya yang lebih murah dari konsentrat buah lain, seperti sirsak, leci atau manggis (Grumezescu dan Holban, 2019). Konsentrat apel digunakan di industri pangan sebagai bahan baku minuman, baik sebagai minuman rekonstitusi atau sebagai bahan pengisi untuk memberi cita rasa buah. Puree konsentrat apel juga banyak digunakan pada produk bakeri yang menggunakan selai untuk memberikan cita rasa buah dan tekstur (Zhou dan Hui, 2014). Tingkat kemanisan konsentrat apel yang tinggi juga menjadi alasan penggunaannya dalam pengembangan produk berkalori rendah atau tanpa penambahan gula.

Dalam kategori pangan, konsentrat apel dikelompokkan ke dalam minuman sari buah dan sayuran. Konsentrat buah didefinisikan sebagai cairan yang diperoleh dari bagian buah yang dapat dimakan yang dicuci, dihancurkan, dijernihkan jika dibutuhkan, dengan atau tanpa pasteurisasi dan dikemas untuk dapat dikonsumsi langsung (BPOM, 2016). Produksi konsentrat apel mencakup tahapan ekstraksi, penyaringan, dan pemekatan. Pada jenis konsentrat apel yang jernih, konsentrat diperoleh dari tahap proses penyaringan dengan menggunakan ultrafiltrasi, sentrifugasi kecepatan tinggi atau filter penukar ion. Pemekatan dilakukan dengan tujuan mengeluarkan air dari sari buah. Beberapa metode yang digunakan untuk pemekatan ini adalah evaporasi panas, distilasi osmosis, dan distilasi membran (Echavarría dkk., 2011; Onsekizoglu dkk., 2010).

Kerusakan utama dari konsentrat apel adalah perubahan warna yang salah satunya disebabkan oleh reaksi pencoklatan enzimatis (Guo dan Qiu, 2010). Buah apel mengandung enzim polifenoloksidase yang berperan dalam reaksi pencoklatan enzimatis yang membentuk pigmen gelap. Reaksi pencoklatan enzimatis pada buah juga mengubah aroma, rasa dan nilai gizinya (Holderbaum dkk., 2010). Selain itu perubahan warna pada konsentrat apel dapat juga disebabkan oleh reaksi pencoklatan non-enzimatis (reaksi Maillard). Senyawa 5-hidroksimetilfurfural (HMF) merupakan marker sari buah yang terbentuk akibat reaksi Maillard. Dengan demikian, sari buah segar tanpa pemanasan tidak mengandung HMF. Pada tahap lanjut, HMF berubah menjadi melanoidin, yang merupakan senyawa pigmen yang memberikan warna coklat (Çoklar dan Akbulut, 2010). Kecepatan reaksi Maillard pada bahan pangan dipengaruhi oleh komposisi gula dan asam amino, aktivitas air, derajat keasaman, dan suhu (CorzoMartínez dkk., 2012; Purlis, 2010).

Pembentukan warna coklat konsentrat apel selama pengolahan dapat terjadi pada tahap pemekatan dengan evaporator. Menurut Echavarría dkk. (2012) pada tahap awal evaporasi dengan multiple-effect evaporator kenaikan suhu tinggi sering terjadi, yang dapat memicu terjadinya reaksi Maillard. Proses pemekatan dengan evaporasi meningkatkan HMF di dalam konsentrat apel (Çoklar dan Akbulut, 2010; Echavarría dkk., 2011). Penggunaan evaporator vakum dan proses dekolorisasi dengan arang aktif dapat menurunkan konsentrasi HMF sehingga dapat memperbaiki kejernihan konsentrat buah (Çoklar dan Akbulut, 2010). Seperti halnya akrilamida, HMF menjadi kontaminan jenis baru yang menjadi perhatian yang diduga bersifat karsinogenik (Capuano dan Fogliano, 2011). Di Indonesia kandungan HMF di dalam madu diatur di dalam SNI dengan batas maksimum 50 ppm (BSN, 2004).

Warna merupakan parameter penting yang menentukan kualitas konsentrat apel. Perubahan warna mengindikasikan penurunan mutu konsentrat apel dan sebagai penentu umur simpannya. Instrumen yang umum digunakan untuk mengukur warna konsentrat buah adalah spektrofotometer (Vaikousi dkk., 2008; Zhu dkk., 2009) atau kolorimeter (Burdurlu dan Karadeniz, 2003; Pathare dkk., 2013; Toribio dan Lozano, 1984). Prinsip kerja kolorimeter adalah mengukur warna obyek melalui tiga komponen, yaitu sumber pencahayaan, filter cahaya dan detektor fotoelektrik. Setiap warna memiliki nilai tristimulus sendiri yang membedakannya dari warna lain. Kolorimeter memberikan pengukuran yang dapat dikorelasikan dengan persepsi mata-otak manusia dan memberikan nilai tristimulus $(L, a$, dan b) secara langsung (Pathare dkk., 2013). Kelemahan evaluasi mutu konsentrat apel dengan menggunakan kolorimeter atau spektrofometer, khususnya untuk diaplikasikan secara praktis di industri pangan, adalah biaya investasi yang cukup mahal, waktu analisis yang relatif lama, dan analisis yang bersifat destruktif yang menyebabkan kehilangan produksi.

Teknologi smartphone yang dilengkapi dengan kamera dan sensor berkinerja tinggi telah berkembang pesat sehingga berpeluang sebagai alternatif mengukur warna konsentrat apel. Dengan didukung aplikasi yang sesuai, pengukuran warna konsentrat apel dengan smartphone lebih praktis, murah dan cepat. Analisis warna berbasis smartphone telah diterapkan dalam analisis konsentrasi fluor di dalam air, senyawa glutamat pada sup instan, alergen kacang tanah pada makanan, grading warna pada anggur merah (Coskun dkk., 2013; 
Levin dkk., 2016; Monošík dkk., 2015; Rateni dkk., 2017; San Park dkk., 2014). Beberapa perkembangan yang mendukung potensi tersebut adalah kemampuan kamera smartphone dalam menghasilkan gambar resolusi tinggi dan peningkatan kinerja prosesor dalam komputasi algoritma.

Berbeda dengan kolorimeter, kamera smartphone mengukur radiasi elektromagnetik dari zona berwarna melalui sensor kamera. Algoritma memproses informasi ini untuk menghasilkan keluaran nilai $R^{\prime}, G^{\prime}$, dan $B^{\prime}$ (red, green, blue) dari nilai $R, G$, dan $B$ sebenarnya. Akurasi pengukuran warna dengan kamera smartphone dipengaruhi oleh pencahayaan, filter cahaya dan algoritma white balance dari kamera. Hal ini mengakibatkan nilai $R^{\prime}, G^{\prime}$, dan $B^{\prime}$ dengan kamera smartphone tidak linier dengan warna obyek sebenarnya. Oleh karena itu, diperlukan faktor koreksi berupa kalibrasi dengan obyek yang telah terstandarisasi nilai RGB-nya. Terminologi faktor koreksi $(\gamma)$ digunakan untuk merumuskan output relatif terhadap input akibat pencahayaan, sehingga kamera smartphone dengan nilai $\gamma$ yang sama dapat menghasilkan output yang sama. Souza dkk. (2018) memperkenalkan nilai warna relatif $(r, g$, dan $b)$ yang menghubungkan nilai $R^{\prime}, G^{\prime}$, dan $B^{\prime}$ (area acuan) dengan nilai $R^{\prime}, G^{\prime}$, dan $B^{\prime}$ (area sampel). Pendekatan warna relatif ini dapat memberikan simpangan baku yang lebih kecil.

Pemanfaatan kamera smartphone Android dalam mengukur perubahan warna konsentrat apel selama penyimpanan dan penggunaannya untuk menduga umur simpannya belum dilaporkan. Dengan demikian, penelitian bertujuan untuk (1) menentukan korelasi hasil pengukuran warna dengan kolorimeter dan kamera smartphone Android pada konsentrat apel model; dan (2) membandingkan hasil pendugaan umur simpan konsentrat apel berdasarkan parameter warna dari kamera smartphone Android dengan kolorimeter.

\section{METODE PENELITIAN}

\section{Bahan dan Alat}

Sampel konsentrat apel terdiri dari dua jenis, yaitu konsentrat apel yang dihilangkan warnanya (decolorized apple concentrate) dan konsentrat apel (Malus domestica). Kedua jenis konsentrat apel tersebut diperoleh dari suplier lokal. Decolorized apple concentrate memiliki total padatan $70^{\circ} \mathrm{Brix}$, $\mathrm{pH} 5,50$, dan kadar asam $<0,10 \%$ (sebagai asam malat), sedangkan konsentrat apel memiliki total padatan $70{ }^{\circ} \mathrm{Brix}, \mathrm{pH} 3,47$, dan kadar asam 1,51\% (sebagai asam malat). Pewarna karamel tipe III yang diperoleh dari suplier lokal digunakan dalam pembuatan model konsentrat apel dengan tingkatan warna coklat yang berbeda.

Pengukuran warna CIE-Lab menggunakan Hunter-Lab Colorimeter Colorquest XE pada iluminan/ observer D65 dan $10^{\circ}$. Kamera smartphone yang digunakan adalah Android MiMax Xiaomi dengan spesifikasi sistem operasi Android 7,0, kamera 16 MP f/2,0 dengan panjang fokus 3,57 mm. Kondisi pencahayaan yang dipakai adalah lampu LED 15 Watt. Jarak kamera dan sampel $12 \mathrm{~cm}$ tanpa flash. Kertas putih ukuran A4 $70 \mathrm{~g}$ merek Paperone diperoleh lokal digunakan sebagai acuan.

\section{Pengukuran Warna}

Tahap pertama penelitian adalah menentukan nilai warna $\left(R^{\prime}, G^{\prime}\right.$, atau $\left.B\right)$ dari kamera smartphone yang memberikan korelasi tertinggi terhadap pengukuran menggunakan kolorimeter. Pada tahap ini digunakan model konsentrat apel. Untuk keperluan tersebut, aplikasi berbasis Android khusus dikembangkan untuk penelitian ini sehingga nilai $R^{\prime}, G^{\prime}$, dan $B^{\prime}$ dari sampel dan acuan dapat langsung diperoleh pada area yang ditentukan (Souza dkk., 2018). Ekstraksi image warna pada Android dilakukan dengan menggunakan metode getPixel (Hermida dkk., 2018; Xiang dkk., 2016). Selanjutnya, nilai warna yang berkorelasi tinggi dipilih sebagai parameter pengukuran warna konsentrat apel selama penyimpanan. Pada tahap ini, digunakan juga nilai warna relatif yang dikembangkan oleh Souza dkk. (2018).

\section{Pemilihan Parameter Warna Kamera Smartphone}

Persiapan model konsentrat apel dengan tingkatan warna coklat yang berbeda dilakukan dengan menambahkan pewarna karamel tipe III ke dalam decolorized apple concentrate pada konsentrasi yang berbeda, yaitu 0,00\%, 0,02\%, 0,04\%, 0,05\%, 0,08\%, dan $0,14 \%(\mathrm{~g} / \mathrm{g})$. Rentang konsentrasi ini dipilih berdasarkan persepsi secara subyektif dari perubahan warna minimum dan maksimum dari konsentrat apel yang umum ditemui di industri konsentrat apel.

Sampel model konsentrat apel diukur dengan kolorimeter untuk mendapatkan nilai $L^{*}, a^{*}$, dan $b^{*}$ dan kamera smartphone Android untuk mendapatkan $R^{\prime}, G^{\prime}$, dan $B^{\prime}$ dari gambar yang ditangkap oleh sampel. Masing-masing nilai $R^{\prime}, G^{\prime}$, dan $B^{\prime}$ merupakan nilai rata-rata pada area gambar sampel $100 \times 150$ piksel. Deteksi nilai $R, G$, dan $B$ dilakukan pada wilayah warna referensi. Konversi $R^{\prime}, G^{\prime}$, dan $B^{\prime}$ menjadi nilai relatif ( $r$, $g$, dan $b$ ) dilakukan dengan menggunakan persamaan 1, 2 dan 3 (Souza dkk., 2018). 
$r=\frac{\ln R^{\prime} \text { (sampel) }}{\ln R^{\prime} \text { (acuan) }}$

$g=\frac{\ln G^{\prime} \text { (sampel) }}{\ln G^{\prime} \text { (acuan) }}$

$b=\frac{\ln B^{\prime} \text { (sampel) }}{\ln B^{\prime} \text { (acuan) }}$

\section{Pendugaan umur simpan warna konsentrat apel}

Sampel konsentrat apel dimasukkan secara aseptik ke dalam tabung polietilen tereftalat (PET) steril (50 $\mathrm{mL}$ ). Tabung kemudian dibungkus dengan aluminum foil dengan tujuan untuk meminimalkan terjadinya oksidasi oleh cahaya. Sampel konsentrat (sebanyak tiga botol) disimpan di dalam tiga inkubator bersuhu $8^{\circ} \mathrm{C}, 15^{\circ} \mathrm{C}$, dan $35^{\circ} \mathrm{C}$. Perubahan warna konsentrat apel selama penyimpanan diukur dengan kamera smartphone dan kolorimeter pada interval 2-5 hari, tergantung masingmasing suhu penyimpanan.

Menurut Kusnandar dkk. (2017), data nilai warna dianalisis kinetika perubahannya dengan menggunakan pendekatan model reaksi ordo 0 dan ordo 1 . Pemilihan ordo reaksi untuk masing-masing nilai warna berdasarkan pada nilai koefisien determinasi $\left(R^{2}\right)$ tertinggi. Selanjutnya data konstanta laju reaksi $(k)$ untuk masing-masing suhu diplotkan ke dalam model Arrhenius (Persamaan 4).

$\ln k=\ln k_{0} \cdot \frac{E a}{R}\left(\frac{1}{T}\right)$

Selanjutnya dari model persamaan Arrhenius tersebut, nilai konstanta laju reaksi pada suhu penyimpanan normal, dan energi aktivasi $\left(E_{a}\right)$ dapat ditentukan (dimana: $k_{0}=$ konstanta reaksi awal, $R$ adalah konstanta gas $(8,314 \mathrm{~J} / \mathrm{molK})$, dan $\mathrm{T}$ adalah suhu $(K)$. Berdasarkan persamaan Arrhenius yang diperoleh, maka dapat ditentukan umur simpan berdasarkan nilai warna yang secara nyata berubah. Warna awal $\left(Q_{j}\right)$ dan akhir $\left(Q_{f}\right)$ umur simpan konsentrat apel menggunakan nilai $L *$, yaitu berturut-turut 85,67 dan 32,84 (masing-masing nilai diperoleh dari uji sensori penerimaan warna).

\section{Analisis Statistik}

Analisis data menggunakan software XLStat (versi 2014). Analisis korelasi Pearson dilakukan untuk menentukan tingkat hubungan antar variabel, analisis regresi dan analisis Bland Altman untuk menentukan tingkat kedekatan (agreement) kedua jenis metode pengukuran. Uji Student dilakukan untuk menentukan perbedaan rata-rata hasil prediksi metode pengukuran pada tingkat signifikansi 0,05.

\section{HASIL DAN PEMBAHASAN}

\section{Korelasi Warna Kolorimeter dan Kamera Smartphone}

Model konsentrat apel dengan tingkatan warna yang berbeda dengan penambahan pewarna karamel III digunakan untuk menguji akurasi hasil pengukuran dengan kamera smartphone dibandingkan kolorimeter. Kedekatan hasil pengukuran dapat dilakukan dengan menggunakan koefisien korelasi ( $r$ ) untuk masing-masing nilai warna. Semakin besar koefisien korelasi, maka semakin kuat resiprokal antar parameter yang terlibat. Pada data yang terkorelasi, perubahan pada suatu parameter berasosiasi terhadap perubahan parameter lainnya, searah jika berkorelasi positif atau berlawanan arah jika berkorelasi negatif (Schober dkk., 2018).

Tabel 1 menyajikan parameter warna yang secara signifikan berkorelasi $(p<0,05)$, kecuali terhadap $B^{\prime}$. $L^{*}$ berkorelasi kuat positif terhadap $R^{\prime}$ dan berkorelasi cukup tinggi dengan $G^{\prime}$. Variabel $a^{*}$ kolorimetri berkorelasi negatif terhadap $R^{\prime}$ dan $G^{\prime}$. Hasil ini sesuai dengan penelitian warna pada keripik kentang yang membandingkan pengukuran kolorimetri dan kamera digital. Kedua pengukuran tersebut memiliki korelasi yang baik dengan kesalahan di level 1,8\% (León dkk., 2006). Dalam hal ini, $R^{\prime}$ memiliki hubungan paling kuat terhadap $L^{*}$ atau $a^{*}$.

Selanjutnya, nilai regresi linier digunakan untuk memprediksi konsentrasi karamel pada model konsentrat. Pada analisis ini juga ditemukan pola yang relatif sama antara pengukuran kolorimetri dan kamera smartphone. Pada pengukuran kolorimetri, konsentrasi karamel meningkat dengan meningkatnya $a^{*}$ atau menurunnya $L^{*}$. Konsentrasi pewarna karamel dapat diprediksi dengan persamaan [\%Karamel] $=0,2801$ $0,0029 \cdot L^{*}$ (dengan koefisien determinasi 0,990). Peningkatan konsentrasi karamel menghasilkan warna yang semakin merah atau semakin gelap.

Regresi linier pengukuran kamera juga sejalan dengan nilai $L^{*}$, dengan koefisien determinasi dari $R^{\prime}$ adalah 0,954, $G^{\prime}=0,691$, dan $B^{\prime}=0,186$. Untuk meningkatkan akurasi dalam memprediksi konsentrasi karamel dengan kamera, maka diperlukan variabel yang memberikan koefisien determinasi yang tinggi $\left(R^{2}>0,950\right)$. Hasil transformasi $R^{\prime}, G^{\prime}$, dan $B^{\prime}$ menjadi warna relatif $r, g$, dan $b$ memberikan nilai warna relatif dengan nilai $R^{2}$ yang lebih baik (untuk $r=0,969$ dan $g=0,876$ ). Hanya transformasi $b$ yang tidak memperbaiki nilai $\mathrm{R}^{2}$.

Selain mempertimbangkan nilai $R^{2}$, hasil transformasi juga dinilai berdasarkan simpangan baku. Simpangan baku yang semakin kecil menunjukkan akurasi data yang semakin baik. Nilai simpangan baku 
Tabel 1. Analisis korelasi kolorimeter dan kamera pada model konsentrat apel

\begin{tabular}{|c|c|c|c|c|c|c|c|c|c|}
\hline & $L^{*}$ & a* & $b^{*}$ & $R^{\prime}$ & $G^{\prime}$ & $B^{\prime}$ & $r$ & $g$ & $b$ \\
\hline [karamel] & $-0,995^{a}$ & $0,971^{a}$ & 0,760 & $-0,979^{a}$ & $-0,843^{a}$ & $-0,484$ & $-0,988^{a}$ & $-0,947^{a}$ & $-0,055$ \\
\hline$L^{*}$ & 1,000 & $-0,962^{a}$ & $-0,808$ & $0,987^{a}$ & $0,879^{a}$ & 0,533 & $0,980^{a}$ & $0,970^{\mathrm{a}}$ & 0,094 \\
\hline a* & & 1,000 & 0,650 & $-0,983^{a}$ & $-0,726$ & $-0,286$ & $-0,989^{a}$ & $-0,904^{a}$ & 0,166 \\
\hline$b^{*}$ & & & 1,000 & $-0,761$ & $-0,983^{a}$ & $-0,797$ & $-0,678^{a}$ & $-0,912^{a}$ & $-0,423$ \\
\hline$R^{\prime}$ & & & & 1,000 & $0,822^{\mathrm{a}}$ & 0,432 & $0,985^{a}$ & $0,958^{a}$ & $-0,024$ \\
\hline$G^{\prime}$ & & & & & 1,000 & $0,813^{a}$ & 0,767 & $0,940^{\mathrm{a}}$ & 0,437 \\
\hline$B^{\prime}$ & & & & & & 1,000 & 0,391 & 0,591 & $0,873^{\circ}$ \\
\hline$r$ & & & & & & & 1,000 & $0,911^{\mathrm{a}}$ & $-0,037$ \\
\hline$g$ & & & & & & & & 1,000 & 0,135 \\
\hline$b$ & & & & & & & & & 1,000 \\
\hline
\end{tabular}

Keterangan: pengukuran dengan kolorimeter $\left(L^{*}, a^{*}\right.$, dan $\left.b^{*}\right)$, pengukuran dengan smartphone $\left(R^{\prime}, G^{\prime}\right.$, dan $\left.B\right)$, dan warna relatif $(r, g$, dan $b)$. Angka dengan a menunjukkan perbedaan nyata pada $(p<0,05)$

$R^{\prime}$ dari $4,6 \%$ dapat diturunkan menjadi $1,36 \%$ setelah ditransformasi menjadi $r$. Demikian juga, transformasi variabel $G^{\prime}$ menjadi $g$ dapat menurunkan simpangan baku dari $14,29 \%$ menjadi $4,89 \%$. Persentase simpangan baku tersebut masih cukup dekat dengan penelitian lain yaitu pada level $1,93 \%$ untuk $r$ dan $3,46 \%$ untuk $g$ (Souza dkk., 2018). Berdasarkan nilai $R^{2}$ dan simpangan baku, maka nilai $r$ dipilih sebagai parameter utama pengukuran kamera yang dapat memberikan akurasi dan berkorelasi yang tinggi dengan nilai $L^{*}$ dari kolorimeter.

Selanjutnya dilakukan validasi untuk melihat akurasi persamaan regresi antara nilai $r$ dan $L^{*}$ dengan nilai aktual (Gambar 1). Regresi liner untuk nilai $r$ menunjukkan nilai $R^{2}=0,969$ dengan simpangan baku $\pm 0,02$. Uji Student hasil prediksi konsentrasi karamel dengan $L^{*}$ kolorimeter dan $r$ kamera tidak berbeda nyata $(p>0,05)$ yang berarti secara statistik tidak ada perbedaan hasil prediksi antara pengukuran dengan kolorimeter $\left(L^{*}\right)$ dan kamera ( $r$ ). Menurut Özgür (2018), korelasi yang tinggi antara kedua jenis pengukuran tidak menjamin kedua pengukuran tersebut berkesesuaian (agreement) satu sama lain yang cukup baik. Untuk itu prediksi konsentrasi karamel melalui pengukuran $L^{*}$ dan $r$ dilanjutkan dengan analisis Bland Altman. Seperti terlihat pada Gambar 2, perbedaan kedua jenis pengukuran berada di dalam rentang kesesuaian yaitu $-0,018 \%-0,016 \%$ ( $\pm 2 x$ simpangan baku). Hal ini berarti bahwa kedua jenis pengukuran $L^{*}$ dan $r$ dapat saling dipertukarkan.

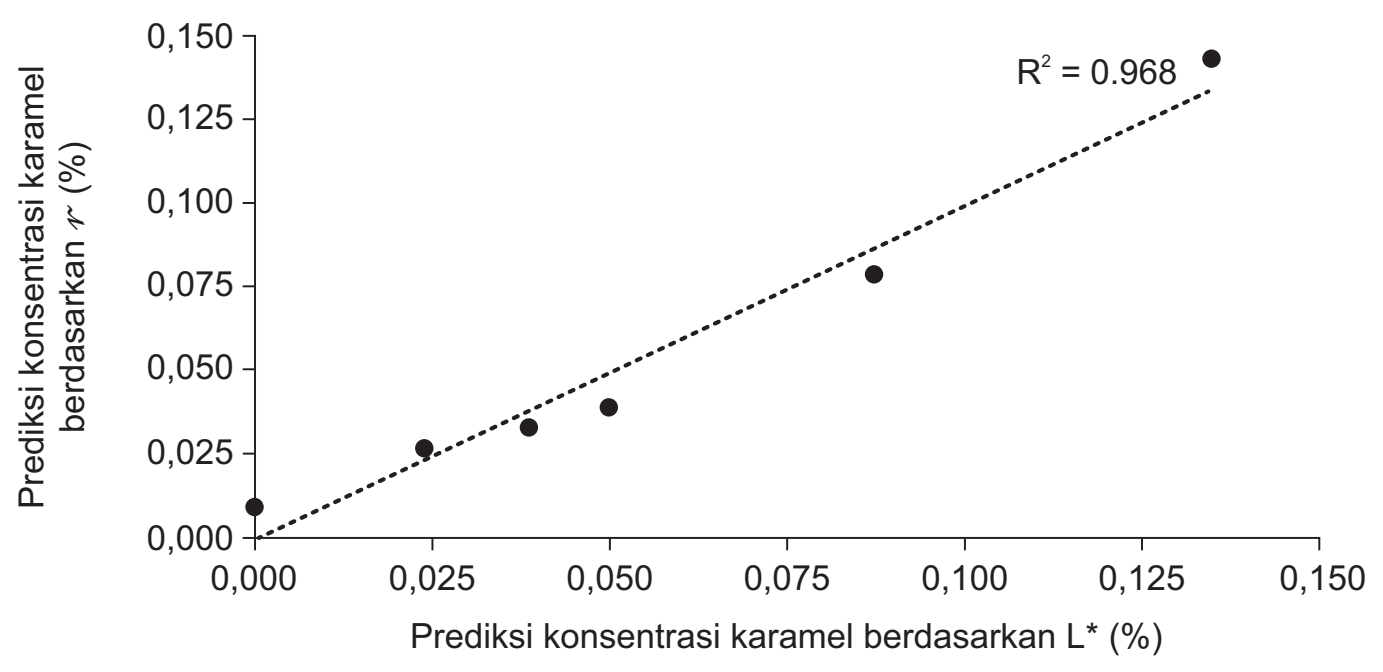

Gambar 1. Regresi linier prediksi konsentrasi karamel menggunakan $L^{*}$ dan $r$ 


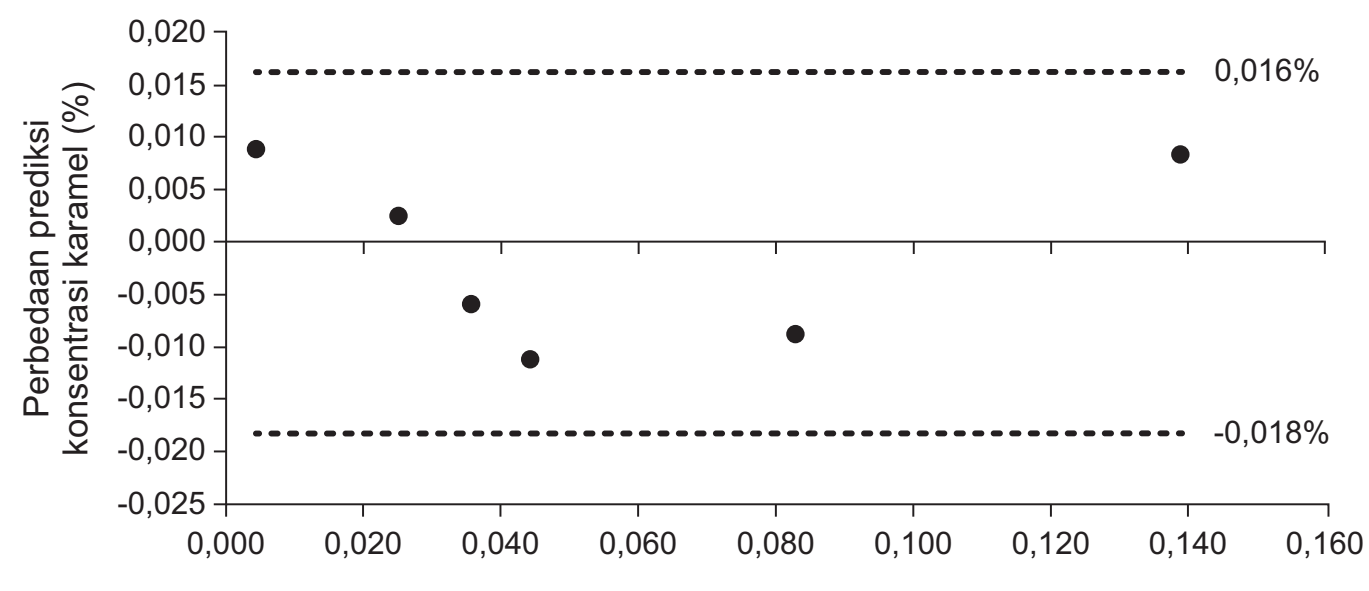

Rata-rata hasil prediksi konsentrasi karamel (\%)

Gambar 2. Kesesuaian (agreement) hasil prediksi konsentrasi karamel pengukuran antara $L^{*}$ dan $r$

\section{Perubahan Warna Konsentrat Apel Selama Penyimpanan}

Gambar 3 menunjukkan perubahan nilai $L^{*}$ dan $r$ pada suhu penyimpanan yang berbeda. Nilai $L^{*}$ dan $r$ menurun selama penyimpanan, yang nilainya cenderung lebih cepat menurun pada suhu penyimpanan yang lebih tinggi. Laju penurunan nilai $L^{*}$ terlihat lebih drastis terjadi pada suhu $35^{\circ} \mathrm{C}$. Hal ini menunjukkan konsentrat apel semakin menurun tingkat kecerahannya (cenderung lebih coklat) yang dapat dipicu oleh adanya reaksi Maillard yang lajunya semakin meningkat pada suhu yang lebih tinggi.

Hasil perhitungan konstanta laju reaksi $(k)$ berdasarkan ordo reaksi 0 dan 1 menunjukkan $R^{2}$ yang tinggi, kecuali pada suhu $8{ }^{\circ} \mathrm{C}$ (Tabel 2). Perubahan yang relatif lambat dan berfluktuasi pada suhu $8{ }^{\circ} \mathrm{C}$

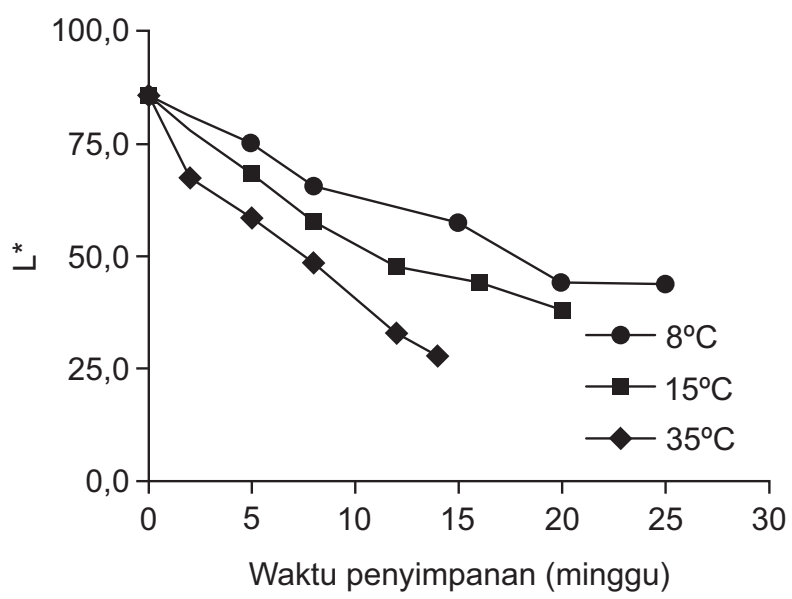

berkontribusi pada nilai $R^{2}$ tersebut. Bila berdasarkan pada suhu penyimpanan yang tinggi, maka ordo reaksi yang dapat dipilih adalah ordo 1 karena memiliki $R^{2}$ yang lebih tinggi. Perbedaan laju reaksi kedua model tidak berbeda signifikan ( $p>0.05)$. Hal ini sesuai dengan reaksi pencoklatan non-enzimatis yang dilaporkan untuk puree apel (Ibarz dkk., 2000), konsentrat apel (Burdurlu dan Karadeniz, 2003) serta sari buah sitrus (Koca dkk., 2003) yang menunjukkan model ordo reaksi 1.

Dengan menggunakan Persamaan 4, maka dapat ditentukan model Arrhenius yang dapat digunakan untuk memprediksi nilai konstanta laju reaksi pada suhu penyimpanan normal (Tabel 3). Energi aktivasi $L^{*}$ dan $r$ yang relatif kecil $(26,00$ dan $40,40 \mathrm{~kJ} / \mathrm{mol})$ menunjukkan hanya sedikit energi yang diperlukan terjadinya perubahan nilai $L^{*}$ atau $r$. Sebagai

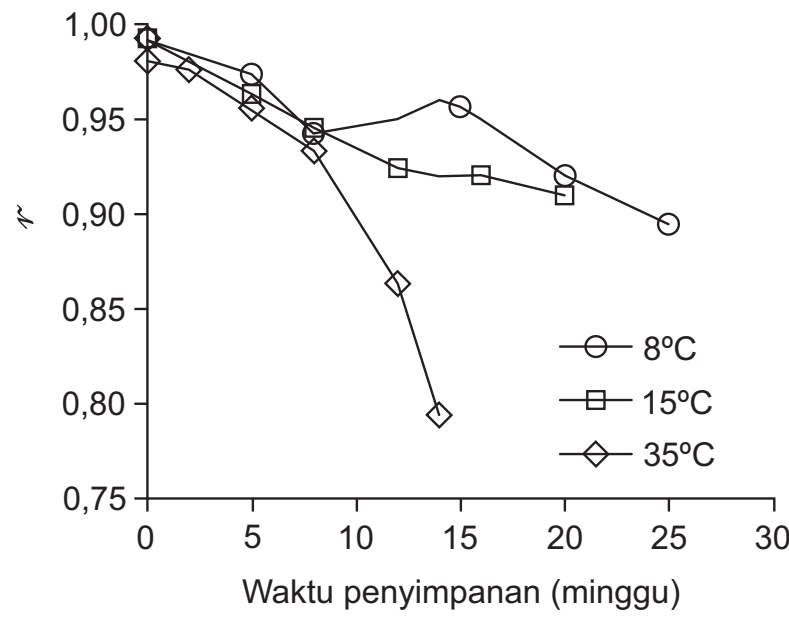

Gambar 3. Pengamatan nilai $L^{*}$ (kolorimeter) dan $r$ (smartphone) konsentrat apel pada beberapa kondisi suhu penyimpanan 
Tabel 2. Konstanta laju reaksi (k) nilai $L^{*}$ (kolorimeter) dan $r$ (smartphone) selama penyimpanan

\begin{tabular}{lcccccc}
\hline \multirow{2}{*}{ Parameter } & \multirow{2}{*}{ Suhu $\left({ }^{\circ} \mathrm{C}\right)$} & \multicolumn{2}{c}{ Ordo 0} & & \multicolumn{2}{c}{ Ordo 1} \\
\cline { 3 - 4 } \cline { 6 - 7 } & & $k$ & $R^{2}$ & & $k$ & $R^{2}$ \\
\hline$L^{*}$ (kolorimeter) & 8 & 1,7407 & 0,961 & & 0,0286 & 0,967 \\
& 15 & 2,3402 & 0,943 & & 0,0405 & 0,980 \\
\multirow{2}{*}{ (smartphone) } & 35 & 3,8770 & 0,972 & & 0,0775 & 0,988 \\
& 8 & 0,0034 & 0,771 & & 0,0036 & 0,771 \\
& 15 & 0,0039 & 0,859 & & 0,0041 & 0,863 \\
& 35 & 0,0135 & 0,909 & & 0,0151 & 0,891 \\
\hline
\end{tabular}

pembanding, pada konsentrat apel Golden Delicious (Burdurlu dan Karadeniz, 2003), energi aktivasi $L^{*}$ pada ordo 1 adalah 36,59 kJ/mol. Perbedaan energi aktivasi kedua hasil penelitian tersebut dimungkinkan terjadi karena varietas apel yang berbeda. Data Burdurlu dan Karadeniz (2003) yang juga membandingkan konsentrat apel Amasya memperoleh energi aktivasi sebesar 75,24 $\mathrm{kJ} / \mathrm{mol}$ (ordo 1). Hal ini menunjukkan konsentrat apel dari varietas tertentu lebih cepat mengalami perubahan pencoklatan dibandingkan varietas yang lain. Perbedaan reaktivitas reaksi Maillard pada konsentrat apel dapat disebabkan oleh perbedaan komposisi bahan seperti jenis gula pereduksi dan asam amino. Menurut Phisut dan Jiraporn (2013), dalam reaksi pencoklatan glukosa lebih reaktif dibandingkan fruktosa, yang mungkin disebabkan oleh sifat gugus karbonil yang lebih reaktif. Dalam hal ini, apel Golden Delicious mengandung lebih banyak glukosa dibandingkan apel Amasya (Karatas dan Akkaya, 2017).

Dengan menggunakan model Arrhenius (Tabel 3), maka dapat dilakukan pendugaan umur simpan pada
Tabel 3. Model Arrhenius nilai $L^{*}$ dan $r$ dari konsentrat apel

\begin{tabular}{cccc}
\hline Parameter & In $k_{0}$ & $E_{a}(\mathrm{~kJ} / \mathrm{mol})$ & $R^{2}$ \\
\hline$L^{*}$ (kolorimeter) & 7,61 & 26,00 & 0,994 \\
$r($ smartphone $)$ & 11,53 & 40,40 & 0,969 \\
\hline
\end{tabular}

berbagai suhu penyimpanan (Gambar 4). Pada suhu penyimpanan $25^{\circ} \mathrm{C}$, umur simpan yang diprediksi hampir sama, yaitu 16,7 minggu (nilai $r$ ) dan 17,2 minggu (dari nilai $L^{*}$ ). Namun, pada suhu penyimpanan yang lebih rendah, prediksi umur simpan mengalami penyimpangan antara kedua parameter tersebut. Prediksi pada suhu yang lebih rendah, prediksi umur simpan $r$ cenderung lebih tinggi dibandingkan $L^{*}$. Misalnya, pada suhu penyimpanan $5{ }^{\circ} \mathrm{C}$, umur simpan berdasarkan nilai $L^{*}$ adalah 36,5 minggu, sedangkan nilai $r$ adalah 53,3 minggu. Prediksi ini diturunkan dari penentuan ordo dan persamaan regresi, yang menurut Valentas dkk. (1997) dipengaruhi kecukupan data perubahan yang diamati.

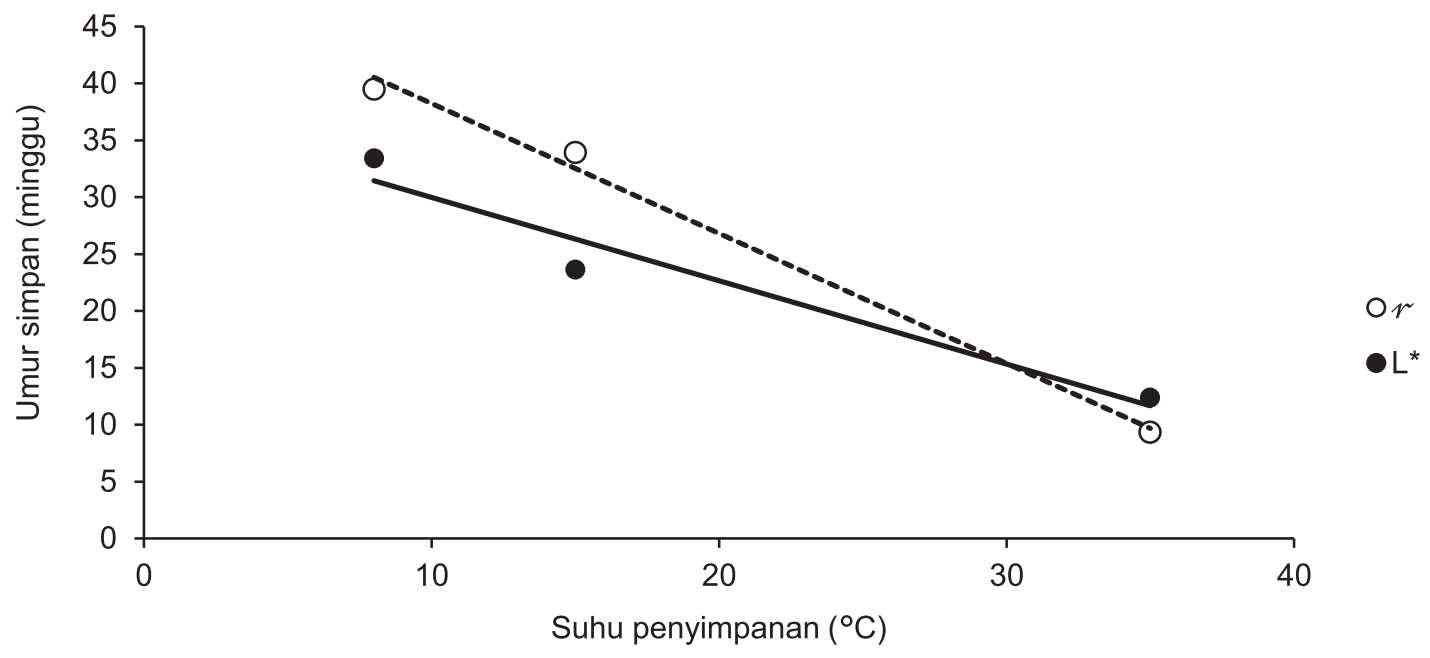

Gambar 4. Prediksi umur simpan konsentrat apel berdasarkan $L^{*}$ (kolorimeter) dan $r$ (smartphone) 
Data pengamatan sebaiknya dilakukan hingga telah terjadi konversi atau perubahan dari warna awal $\left(Q_{i}\right)$ pada kisaran $50-75 \%$. Pada penelitian ini, pengukuran $L^{*}$ pada suhu $8{ }^{\circ} \mathrm{C}$ terlihat belum mencapai persentase perubahan $Q_{i}$ yang disarankan.

Untuk mengatasi adanya deviasi prediksi umur simpan dari model persamaan Arrhenius di atas, terutama untuk memprediksi umur simpan pada suhu rendah, maka dikembangkan model persamaan koreksi untuk menduga umur simpan dari nilai $r$ agar mendekati prediksi umur simpan dari nilai $L^{*}$. Model persamaan dapat diturunkan dari analisis regresi linier (MacKenzie, 2013) atau nonlinier (kuadratik, eksponensial, kubik dan geometrik) (Archontoulis dan Miguez, 2015). Model persamaan yang dipilih berdasarkan pada nilai koefisien determinasi $\left(R^{2}\right)$ dan adjusted $R^{2}$ yang paling tinggi, dan kesalahan baku (standard error) yang paling rendah. Berdasarkan pendekatan tersebut, model geometrik persamaan 5 yang dipilih $\left(R^{2}=0,999\right.$, adjusted $R^{2}=0,998$, dan kesalahan baku=0,001). Sebagai contoh, dengan menggunakan persamaan tersebut, maka umur simpan konsentrat apel berdasarkan nilai $r$ pada suhu $5^{\circ} \mathrm{C}$ adalah 36,5 minggu yang relatif sama berdasarkan nilai $L^{*}$.

$t_{r^{\prime}}=2,82 \cdot t_{r}^{0,64}$

\section{KESIMPULAN}

Nilai warna relatif $R^{\prime}$ dari pengukuran warna konsentrat apel dengan menggunakan kamera smartphone berkorelasi tinggi dengan nilai $L^{*}$ dari pengukuran kolorimeter. Transformasi nilai $R^{\prime}$ menjadi nilai $r$ meningkatkan nilai korelasi dan menurunkan simpangan baku dari persamaan regresi model konsentrat apel. Pendugaan umur simpan dengan nilai $r$ memberikan hasil yang relatif sama dengan nilai $L^{*}$, terutama pada suhu $25^{\circ} \mathrm{C}$, yaitu 17,2 minggu $\left(L^{*}\right)$ dan 16,7 minggu $(r)$. Pada suhu yang rendah, prediksi umur simpan dengan menggunakan nilai $r$ mengalami penyimpangan. Penggunaan persamaan koreksi dapat memperbaiki hasil prediksi umur simpan dengan nilai $r$.

\section{KONFLIK KEPENTINGAN}

Penulis menyatakan tidak ada konflik atau kepentingan dengan pihak lain.

\section{DAFTAR PUSTAKA}

Archontoulis, S. V, \& Miguez, F. E. (2015). Nonlinear regression models and applications in agricultural research. Agronomy Journal, 107(2), 786-798. https:// doi.org/10.2134/agronj2012.0506

BPOM. (2016). Peraturan Kepala Badan Pengawasan Obat dan Makanan Republik Indonesia Nomor 21 Tahun 2016 Tentang Kategori Pangan. Jakarta (ID): BPOM.

BPS. (2018). Tabel Impor Menurut Komoditi Tahun 2018. Retrieved November 4, 2019, from https://www.bps. go.id/all_newtemplate.php

BSN. (2004). SNI 01-3545-2004 Madu. Jakarta (ID): Badan Standarisasi Nasional.

Burdurlu, H. S., \& Karadeniz, F. (2003). Effect of Storage on Nonenzymatic Browning of Apple Juice Concentrates. Food Chemistry, 80(1), 91-97. https://doi.org/10.1016/ S0308-8146(02)00245-5

Capuano, E., \& Fogliano, V. (2011). Acrylamide and 5-Hydroxymethylfurfural (HMF): a Review on Metabolism, Toxicity, Occurrence in Food and Mitigation Strategies. LWT - Food Science and Technology, 44(4), 793-810. https://doi.org/10.1016/j.Iwt.2010.11.002

Çoklar, H., \& Akbulut, M. (2010). Effect on Phenolics, HMF and Some Physico-chemical Properties of Apple Juice Concentrate of Activated Carbon Applied at the Different Temperatures. Journal of Food Process Engineering, Vol. 33, pp. 370-383. https://doi.org/10.1111/j.17454530.2008.00280.x

Corzo-Martínez, M., Corzo, N., Villamiel, M., \& del Castillo, M. D. (2012). Browning Reaction in Food Biochemistry and Food Processing. In B. Simpson, L. Nollet, G. Paliyath, S. Benjakul, \& Y. Hui (Eds.), Browning Reaction (2nd ed.). https://doi.org/10.1002/9781118308035.ch4

Coskun, A. F., Wong, J., Khodadadi, D., Nagi, R., Tey, A., \& Ozcan, A. (2013). A Personalized Food Allergen Testing Platform on a Cellphone. Lab on a Chip, 13(4), 636-640. https://doi.org/10.1039/c2lc41152k

Echavarría, A. P., Pagán, J., \& Ibarz, A. (2012). Melanoidins Formed by Maillard Reaction in Food and Their Biological Activity. Food Engineering Reviews, 4(4), 203-223. https://doi.org/10.1007/s12393-012-9057-9

Echavarría, A. P., Torras, C., Pagán, J., \& Ibarz, A. (2011). Fruit Juice Processing and Membrane Technology Application. Food Engineering Reviews, 3(3-4), 136-158. https:// doi.org/10.1007/s12393-011-9042-8

Grumezescu, A., \& Holban, A.-M. (2019). Quality Control in the Beverage Industry Volume 17. Duxford (GB): Elsevier.

Guo, S., \& Qiu, N. (2010). Kinetics and Influencing Factors of Nonenzymatic Browning in Apple Juice Concentrate. Food Science, 31(23), 79-83.

Hermida, I. D. P., Prabowo, B. A., Kurniawan, D., Manurung, R. V, Sulaeman, Y., Riyadi, M. A., \& Wahono, M. D. (2018). Use of Smartphone Based on Android as a Color Sensor. 2018 
Electrical Power, Electronics, Communications, Controls and Informatics Seminar (EECCIS), (March 2020), 424429. https://doi.org/10.1109/EECCIS.2018.8692848

Holderbaum, D. F., Kon, T., Kudo, T., \& Guerra, M. P. (2010). Enzymatic Browning, Polyphenol Oxidase Activity, and Polyphenols in Four Apple Cultivars: Dynamics during Fruit Development. HortScience, 45(8), 1150-1154. Retrieved from http://hortsci.ashspublications.org/ content/45/8/1150.short

Ibarz, A., Pagan, J., \& Garza, S. (2000). Kinetic Models of Nonenzymatic Browning in Apple Puree. Journal of the Science of Food and Agriculture, 80(8), 1162-1168. https:// doi.org/10.1002/1097-0010(200006)80:8<1162::AIDJSFA613>3.0.CO;2-Z

Karatas, S., \& Akkaya, D. (2017). Effect of storage temperature on Hydroxymethylfurfural contents in apple juice. Chemistry Research Journal, 2(1), 12-19. https://doi. org/10.1007/s10162-016-0594-4

Koca, N., Burdurlu, H. S., \& Karadeniz, F. (2003). Kinetics of Nonenzymatic Browning Reaction in Citrus Juice Concentrates during Storage. Turkish Journal of Agriculture and Forestry, 27(6), 353-360.

Kusnandar, F., Khonza, M., \& Budijanto, S. (2017). Perubahan Mutu Beras Analog Jagung Selama Penyimpanan dan Penentuan Umur Simpannya dengan Metode Arrhenius. Jurnal Mutu Pangan, 4(2), 51-58.

León, K., Mery, D., Pedreschi, F., \& León, J. (2006). Color Measurement in $L^{*} a * b *$ Units from RGB Digital Images. Food Research International, 39(10), 1084-1091. https://doi.org/10.1016/j.foodres.2006.03.006

Levin, S., Krishnan, S., Rajkumar, S., Halery, N., \& Balkunde, P. (2016). Monitoring of Fluoride in Water Samples Using a Smartphone. Science of the Total Environment, 551-552, 101-107. https://doi.org/10.1016/j.scitotenv.2016.01.156

MacKenzie, I. S. (2013). Human-Computer Interaction: An Empirical Research Perspective.

Monošík, R., Bezerra Dos Santos, V., \& Angnes, L. (2015). A Simple Paper-strip Colorimetric Method Utilizing Dehydrogenase Enzymes for Analysis of Food Components. Analytical Methods, 7(19), 8177-8184. https://doi.org/10.1039/c5ay01556a

Onsekizoglu, P., Bahceci, K. S., \& Acar, M. J. (2010). Clarification and the concentration of apple juice using membrane processes: A comparative quality assessment. Journal of Membrane Science, 352(1-2), 160-165. https://doi. org/10.1016/j.memsci.2010.02.004

Özgür, N. (2018). Bland-Altman Analysis : a Paradigm to Understand Correlation and Agreement. Turkish Journal of Emergency Medicine, 18(4), 139-141. https://doi. org/10.1016/j.tjem.2018.09.001
Pathare, P. B., Opara, U. L., \& Al-Said, F. A. J. (2013). Colour Measurement and Analysis in Fresh and Processed Foods: a Review. Food and Bioprocess Technology, 6(1), 36-60. https://doi.org/10.1007/s11947-012-0867-9

Phisut, N., \& Jiraporn, B. (2013). Characteristics and antioxidant activity of Maillard reaction products derived from chitosan-sugar solution. International Food Research Journal, 20(3), 1077-1085.

Purlis, E. (2010). Browning Development in Bakery Products a Review. Journal of Food Engineering, 99(3), 239-249. https://doi.org/10.1016/j.jfoodeng.2010.03.008

Rateni, G., Dario, P., \& Cavallo, F. (2017). Smartphonebased Food Diagnostic Technologies: a Review. Sensors (Switzerland), 17(6). https://doi.org/10.3390/ s17061453

San Park, T., Baynes, C., Cho, S. I., \& Yoon, J. Y. (2014). Paper Microfluidics for Red Wine Tasting. RSC Advances, 4(46), 24356-24362. https://doi.org/10.1039/c4ra01471e

Schober, P., Boer, C., \& Schwarte, L. A. (2018). Correlation Coefficients: Appropriate Use and Interpretation. Anesthesia Analgesia, 126(5), 1763-1768. https://doi. org/10.1213/ANE.0000000000002864

Souza, W. S., de Oliveira, M. A. S., de Oliveira, G. M. F., de Santana, D. P., \& de Araujo, R. E. (2018). Self-Referencing Method for Relative Color Intensity Analysis Using Mobile-Phone. Optics and Photonics Journal, 08(07), 264-275. https://doi.org/10.4236/opj.2018.87022

Toribio, J. L., \& Lozano, J. E. (1984). Nonenzymatic Browning in Apple Juice Concentrate during Storage. Journal of Food Science, 49(3), 889-892. https://doi. org/10.1111/j.1365-2621.1984.tb13234.x

Vaikousi, H., Koutsoumanis, K., \& Biliaderis, C. G. (2008). Kinetic Modelling of Non-enzymatic Browning of Apple Juice Concentrates Differing in Water Activity under Isothermal and Dynamic Heating Conditions. Food Chemistry, 107(2), 785-796. https://doi.org/10.1016/j. foodchem.2007.08.078

Valentas, K. J., Rotstein, E., \& Singh, R. P. (Eds.). (1997). Handbook of Food Engineering Practice. New York (US): CRC Press.

Xiang, M., Wei, S., \& Li, M. Z. (2016). ScienceDirect Realtime Monitoring System of Agricultural Real-time Based. IFAC-PaperOnline, 49-16, 121-126. https://doi. org/10.1016/j.ifacol.2016.10.023

Zhou, W., \& Hui, Y. H. (2014). Bakery Products Science and Technology. Chichester (GB): Wiley Blackwell.

Zhu, D., Qing, Z., Ji, B., \& Zude, M. (2009). Analyzing the Browning of Apple Juice by Fluorescence Spectroscopy. Food Chemistry, 133, 272-279. https://doi.org/10.1016/j. foodchem.2008.07.009 